\title{
THE LIABILITY OF PROFESSIONAL TEAM SPORTS PHYSICIANS
}

\author{
Lonny Balbi*
}

\begin{abstract}
Sports medicine is emerging as a new specialized field of medicine. The author discusses the liability of doctors working for professional sports teams and the problems of using a standard of care similar to that used in other medical negligence suits. Other possible standards of care are outlined and analyzed.
\end{abstract}

\section{INTRODUCTION}

Canada has recently undergone a tremendous increase in litigation in the area of sport-related torts. This is evidenced by a recent survey on Canadian sports torts which indicated that the parties to the various actions included athletes, team owners, team management, spectators, facility operators, persons outside sports facilities, sports equipment manufacturers, sports governing bodies and coaches. ${ }^{1}$ The thrust in most of these actions was that personal injury resulted to one party due to some negligent conduct or activity on the part of the other party. In none of the actions was there any question of a team physician misinforming or failing to inform an athlete about risks which could affect the athlete's decision to participate.

Accompanying this trend of increased litigation in the area of sports related negligence has been a number of current developments in the law of medical malpractice - particularly in the context of informed consent. ${ }^{2}$ The thrust of these cases was not that the execution of the surgery or treatment was negligently performed, but was that the physician failed to properly disclose any material risks prior to the surgery or treatment.

Despite the fact that the sports tort and the physician liability lines of cases have been running in parallel, it is clear that there has been no confluence of the two. The sports tort cases focus on normal negligence principles with particular emphasis on the athlete's assumption of risk, whereas the physician liability cases focus on the patient's lack of informed consent prior to surgery or treatment. Together, these separate lines of cases can be combined to result in a situation where a team physician misinforms or fails to inform an athlete about the risks attendant upon a particular activity, and injury results to the athlete. More specifically, the situation envisioned is one where a professional sports team hires a physician in order to prevent and treat injuries which arise from participation in the sport. The team physician's potential liability emanates where he fails to discover or to disclose material risks of treatment or he negligently executes the treatment, ${ }^{3}$ and physical or economic loss ${ }^{4}$ results to the athlete. Under normal circumstances in the non-athlete situation, the physician would be held to have owed the patient a duty of care because

* BComm. (Dist.) (Calg.) LL.B. (Sask.), has recently completed his articles in Calgary, Alberta.

1. J. Barnes, “Canadian Sports Torts: A Bibliographical Survey" (1979) 8 C.C.L.T. 198.

2. Hopp v. Lepp (1980) 112 D.L.R. (3d) 67 (S.C.C.); Reib/ v. Hughes (1980) 114 D.L.R. (3d) 1 (S.C.C.); Videto v. Kennedy (1981) 125 D.L.R. (3d) 127 (Ont. C.A.).

3. This topic is covered in detail in Part IV, infra.

4. For a discussion of the problems relating to physical and in particular economic loss, see Part IV(A) and (B), infra. 
of the doctor-patient relationship, and the standard would be that of the reasonable physician in similar circumstances. ${ }^{5}$ However, the circumstances which a team physician finds himself in are definitely not normal. First, the physician is employed not by the patient/athlete, but by the team. In these circumstances the doctor-patient relationship may not exist in its traditional form. It is therefore possible that the team physician owes no duty of care to the athlete. ${ }^{6}$ Second, even if a duty of care is found to exist, there is the formidable obstacle of determining the appropriate standard of care required of team physicians. This unusual situation which a team physician finds himself in is characterized by the clear presence of pressure originating from both the athlete and team management.7 Furthermore there is no nationally recognized custom or level of expertise required of professional team sports physicians. The standard of care would, therefore, require a determination on some other basis.

There has been no Canadian litigation or commentary regarding the legal liability of professional team sports physicians. But this does not mean the area should continue to be ignored. Both the cases on sports torts $s^{8}$ and those on medical malpractice ${ }^{9}$ have rapidly advanced the law in the last few years. In the near future, team physician liability is bound to come to the forefront as the legal principles enunciated by the two lines of cases are better understood and the situations a team physician finds himself in are more closely analyzed. With this in mind, the purpose of this paper is to survey cases on sports torts and medical malpractice with the view to developing guidelines for both the injured professional athlete and the potentially negligent professional team physician, with particular emphasis given to the establishment of an appropriate duty and standard of care.

\section{BACKGROUND}

The professional team retains the team physician primarily to treat athletic injuries, with minor emphasis on injury prevention. ${ }^{10}$ The physician does not contract with each individual player, only with the team. On the other hand, each player signs a contract with the team, and these contracts include provisions to allow the team physician to examine the athlete in the event an injury occurs during the course of employment. For example, the current N.H.L. Standard Player's Contract provides:

5. (a) Should the Player be disabled or unable to perform his duties under this contract he shall submit himself for medical examination and treatment by a physician selected by the Club. ...

(d) ... if the Player, in the sole judgment of the Club's physician, is disabled and unable to perform his duties as a hockey player by reason of an injury sustained during the course of his employment as a hockey player...

5. Wilson v. Swanson (1956) 5 D.L.R. (2d) 113 (S.C.C.).

6. See Part $\mathrm{V}$, infra.

7. See Part VI, infra.

8. Supran. 1 at 199.

9. Hopp v. Lepp, Reiblv. Hughes, supra n. 2.

10. Interview, Dr. Peter Boucher, a professional team physician with the Edmonton Eskimos Football Club of the Canadian Football League. 
It is not uncommon for the team to refer an athlete to a second physician on an "office consultation basis"." In this case, the physician bills the provincial medical services association rather than the team for services rendered during the of fice visit. ${ }^{12}$

An active athlete may suffer injuries in a variety of ways, the most obvious being an injury which results from the inherent risk involved in participating in that sport. No liability necessarily follows. However, there are a variety of circumstances where the athlete may suffer injuries which are traceable back to the team physician's negligence. Some examples of injuries which may result in liability would be where the physician administers poison rather than pain reliever; where he inadvertently discovers a cancerous skin condition and yet does not mention this to the athlete; or where the physician discovers that the x-ray taken to examine bruised ribs also reveals inflamed kidneys due to alcoholism, and nothing is said to the athlete. In any of these cases, the resultant harm may be either physical damage or pure economic loss. How the law will handle these situations is unclear. Yet the importance of the law is of major concern.

\section{IMPORTANCE OF THE AREA}

When an athlete is injured through the alleged negligence of the team or its physician, the athlete will generally focus his efforts for recovery on the team since its assets would more than likely satisfy judgment. The general nature of an independent action would be for the team's negligence in failing to take proper care of its employees. However, where no fault can be placed on the team, it is important to consider the liability of the team physician in order to find the team vicariously liable. Furthermore, the team's liability may be limited or excluded by contract or legislation, and the importance of being able to sue the team physician personally becomes obvious. ${ }^{13}$

On the other hand, the team physician would be interested in evaluating the parameters of his liability in light of the nature of his employment. As the law is unclear, the team physician has no guidelines on which to base his actions. As well, a team physician would be interested in how his liability could be limited in the context of sports medicine. An exploration of these issues will highlight the importance of the area to both the athlete and the physician.

\section{A. ATHLETE}

Once a professional athlete is injured because of the negligence of the team management or its physician, the damages which result can be substantial. Not only will all special damages (including lost salary to date of trial) be recoverable, but also all general damages (including a considerable sum for loss of future income and benefits). ${ }^{14} \mathrm{~A}$ very real

11. Interview, Dr. Bryan Redpath, Chiropractor, who is often referred to by the Edmonton Eskimos Football Club.

12. Robitaillev. Vancouver Hockey Club(1979) 19 B.C.L.R. 158 at 174 (B.C.S.C.).

13. Assuming the team physician is not an employee of the team, but an independent contractor.

14. K. Cooper-Stephenson and I. Saunders, Personal Injury Damages in Canada (1981) 47. 
problem to the injured athlete is whether or not he will be able to collect on the judgment. ${ }^{15}$ From a practical point of view, an employer is generally better able to satisfy judgments than is an employee, and this holds true for professional sports.

Where no fault for the athlete's injuries can be placed directly on team management the athlete may have another route to finding the organization liable, and that is an action based on vicarious liability. The requirements for vicarious liability in this case would be that the team physician must be an employee or agent of the team management, and his actions must constitute negligence in the course of his employment. ${ }^{16}$

There are occasions where the athlete may be precluded from suing the team management because the standard player's contract between the team and the player and/or the collective bargaining agreement between the league and the players' association excludes team liability for negligence. ${ }^{17}$ If such an exclusion was held to be effective, the only method of recovery for the injured athlete would be to sue the physician directly and personally.

Exclusions in contracts are based on the premise that the parties to the contract are free to waive their legal rights. Once the athlete signs the contract, he is bound by its terms notwithstanding his lack of knowledge of its contents. ${ }^{18}$ The strength of the exclusion clause is increased by the parol evidence rule which excludes extrinsic oral or written evidence in the construction of contracts. ${ }^{19}$ The exclusion of liability must, however, refer specifically to negligence, otherwise a narrower meaning will be attached to it. ${ }^{20}$

Even though it may be possible for the team to protect itself with a properly drafted exclusion clause, ${ }^{21}$ there is a line of cases which indicate that the parties to a contract cannot limit the liability of a party not privy to that contract. ${ }^{22}$ The privity of contract rule was established to allow only the party to the contract to sue on it, for it was that party who provided the consideration. ${ }^{23}$ Thus, the team physician who is an employee of the team would be precluded from relying on the protection of a well drafted exclusion clause where he is not a party to the contract containing that clause.

15. C.R.B. Dunlop, Creditor-Debtor Law in Canada (1981) 125.

16. J. Fleming, The Law of Torts (5th ed. 1977) 478. For a further discussion of the relationship between the team and the physician, see infra n. 26 and accompanying text.

17. Clause 5 of the N.H.L. Standard Player's Contract states: ". . . the Player releases the Club from any and every additional obligation, claims or demand whatsoever."

18. L'Estrangev. Graucob(1934) 2 K.B. 394.

19. Goss v. Lord Nugent (1833) 110 E.R. 713.

20. White v. Warwick, (1953) 1 W.W.R. 285 (C.A.); Robert Simpson Regina Ltd. v. Dominion Electric Protection Co. (1971) 19 D.L.R. (3d) 218 (Sask. Q.B.).

21. The ability of a party to exclude liability for negligence has been restricted by the use of the doctrine of fundamental breach: see infra n. 79 and accompanying text.

22. Scruttons Ltd. v. Midland Silicones Ltd., (1962) A.C. 446 (H.L.); Canadian General Electric Co. Ltd. v. Pickford \& Black Ltd. (1970), 14 D.L.R. (3d) 372 (S.C.C.).

23. Tweddlev. Atkinson (1861) 121 E.R. 762. 
The privity of contract rule has been attacked ${ }^{24}$ on many grounds, and various exceptions have been established. ${ }^{25}$ Where, for example, the physician's relationship with the team can be characterized as one of agent and principal, then reliance can be placed on the exclusion clause. ${ }^{26}$

Where the physician is neither the employee nor the agent of the team, he may be characterized as an independent contractor, and thus would be liable personally for his negligence. The primary test in determining the nature of the relationship between the team and the physician is one of control:27 did the team have the power to select, control and dismiss the physician? If so, the physician is an employee of the team and vicarious liability will result. ${ }^{28}$

The athlete may also be precluded from suing the team because of Workers' Compensation legislation. Generally this legislation replaces an employee's right to sue his employer or fellow worker for an uncertain, but full recovery under common law tort liability with a certain, but limited award. ${ }^{29}$ Most jurisdictions, however, exclude professional teams from the application of the legislation. ${ }^{30}$

And last, sports physician liability is important to the athlete because a determination of an appropriate duty and standard of care required of team physicians allows the athlete to form reasonable expectations with regard to health care in sports medicine. Simply because the expectation of the athlete is high does not necessarily mean the performance of the team physician was substandard; perhaps the expectation was unreasonable.

\section{B. PHYSICIAN}

The team physician is obviously interested in his potential liability for treating team members. ${ }^{31}$ It is important that he should know the standard of care legally required of him in the unique field of sports medicine. Although the cases on general medical malpractice are not totally congruent with sports physician liability, analogies can be drawn to give the physician some guidance on how to conduct his affairs.

Furthermore, both the team and the physician would be interested in determining how to limit the physician's liability to the athlete. From the physician's standpoint, perhaps present methods of liability exclusion are ineffective and better methods could be developed.

24. Supra, n. 16 at 281-282.

25. The exceptions include legislative enactments, collateral contracts, agency and attornment; see S.M. Waddams, The Law of Contracts (1977) 167.

26. Supra n. 16 at 357-358.

27. Sisters of St. Joseph of the Diocese of London v. Fleming, (1938) 2 D.L.R. 417 (S.C.C.).

28. Supra n. 12 at $171-175$ for an application of the control test to a professional team sports physician.

29. J. Weistart \& C. Lowell, The Law of Sports (1979) 1008.

30. See for example in Alberta, Workers' Compensation Act, Alta. Reg. 1187/81, Schedule " A" of exempted industries: professional sports, operation of football clubs, operation of hockey clubs; or in Saskatchewan, Workers' Compensation Act, Sask. Reg. 278/80, s. 3 excluded industries: sports professionals, sport instructors, players and coaches.

31. Team physicians are generally covered by malpractice insurance paid for by the team. Even though the physician would not be the party paying for the liability, his reputation and future chances of success as a physician would be damaged. 


\section{MEDICAL MALPRACTICE GENERALLY}

Since there are no reported Canadian cases which focus on the issue of the liability of professional team physicians, ${ }^{32}$ an analysis of the general principles of medical malpractice will be useful in determining the outcome of a case dealing with team physician liability. A further analysis of the factors which alter the nature of the relationship in context of sports medicine will show how the general principles require special application.

The most common form of medical malpractice is where the alleged conduct of the physician is said to be negligent. ${ }^{33}$ Once all the elements of a negligence action are proved, the injured plaintiff recovers a damage award for his losses.

The negligence action is multifaceted in that liability can be found for a breach of any one of a number of duties. For example, a physician may be liable for failing to treat a patient once he has undertaken to do so, ${ }^{34}$ or he may be liable for failing to count the sponges used during surgery..$^{35}$ In the context of the liability of a team physician there are two general situations which are noteworthy. The first is where the physician fails to disclose or discover material risks which the athlete ought to have been informed of before participating or being treated. The second is where the treatment itself is performed negligently. The harm suffered in either case may be physical or economic loss.

\section{A. INFORMED CONSENT}

In the hallmark cases of Hopp v. Lepp and Reibl v. Hughes, ${ }^{36}$ the Supreme Court of Canada has cleared up much of the confusion which previously existed in the area of battery and negligence in medical malpractice. The intentional tort of battery has been restricted to situations where the physician invades the patient's right to determine what shall be done to his own body and this invasion was totally uncontested by the patient. ${ }^{37}$ On the other hand, negligence would apply where the physician breaches his duty to inform the patient of material risks involved in the treatment, and damage results. ${ }^{38}$ Therefore, an action in negligence will be a more common claim than one in battery.

The issue of informed consent is relevant to team physician liability since there are a number of instances where the physician's omission to inform the athlete about a discovered (or reasonably discoverable) condition results in damage and the damage could have been avoided had the athlete been aware of the condition. More specifically, if the team physi-

32. For example, in Robitaille v. Vancouver Hockey Club, supra n. 12, a professional hockey player was injured through the alleged negligence of both the team management and the club doctors. The case, however, only concentrated on the team's liability. In dealing with the issue of vicarious liability, the trial judge merely assumed negligence on the part of the team physicians; no legal analysis was attempted in this regard. See especially at 175 .

33. E. Picard, Legal Liability of Doctors and Hospitals in Canada (1978) 49.

34. Dangerfield v. David (1910) 17 W.L.R. 249 at 257 (Sask. S.C.).

35. Anderson v. Chasney (1949) 4 D.L.R. 71 (Man. C.A.); affirmed (1950) 4 D.L.R. 223 (S.C.C.).

36. Supran. 2.

37. Reiblv. Hughes, supra n. 2 at 10.

38. Hoppv. Lepp, supran. 2 at 81 ; Reiblv. Hughes, supran. 2 at 5. 
cian examines the athlete during training camp in order to assess fitness levels, or examines the athlete in order to assess the athlete's trade prospects and some latent condition is discovered or ought reasonably to have been discovered and this condition is not communicated to the athlete, the physician may be negligent.

\section{B. NEGLIGENT TREATMENT}

There is a general duty placed on members of society not to injure others. ${ }^{39}$ The same is true for physicians. The unattentive physician on a hunting trip who inadvertently harms another hunter is as liable for negligence as is any other person. However, where a physician undertakes to perform surgery or treatment, he does so without guaranteeing results. ${ }^{40}$ Therefore, the mere existence of an injury derived from a physician's acts is not conclusive of negligence.

Negligence will be found in cases where the physician fails to meet the standards of a similarly qualified physician in like circumstances, ${ }^{41}$ or where the physician goes beyond the necessary treatment and injures other tissues or organs. ${ }^{42}$

In the context of sports physician liability, the issue of negligent treatment is not a particular problem because any harm resulting from substandard treatment would tend to occur in situations closely analagous to those found in the general malpractice cases. Medical malpractice principles relating to emergencies, ${ }^{43}$ treatment, ${ }^{44}$ and controlled surgery ${ }^{45}$ could easily be adapted to sports medicine malpractice.

\section{PHYSICAL OR PURE ECONOMIC LOSS}

The injury resulting from a physician's negligence need not only be physical loss, but may include pure economic loss as well.

\section{Physical Loss}

The usual situation in medical malpractice cases is one where the negligence of the physician causes physical injury to the plaintiff. The plaintiff is entitled to recover out-of-pocket costs prior to the trial, lost future income, future cost of care and other expenses, and non-pecuniary loss. ${ }^{46}$ Any economic loss which is attributable to the physical damage is recoverable as a matter of course.

Recovery for physical loss is controlled by the concept of foreseeability: the physician is only liable for damages which are foreseeable to a reasonable physician in like circumstances. ${ }^{47}$ Any loss which is too

39. Donoghuev. Stevenson (1932) A.C. 562 (H.L.).

40. Johnstonv. Wellesley Hospital (1970) 17 D.L.R. (3d) 139 (Ont. H.C.).

41. Supran. 5.

42. Melvin v. Graham, (1973) D.R.S. 659 (Ont. H.C.).

43. Marshallv. Curry, (1933) 3 D.L.R. 260 (N.S.S.C.).

44. Vailv. MacDonald, (1976) 66 D.L.R. (3d) 530 (S.C.C.).

45. McKeachiev. Alvarez(1970) 17 D.L.R. (3d) 87 (B.C.S.C.).

46. Andrews v. Grand \& Toy Alta. Ltd. (1978) 83 D.L.R. (3d) 452 (S.C.C.).

47. "Wagon Mound"'(1961) A.C. 388 (P.C.). See also Cardin v. Montreal (1961) 29 D.L.R. (2d) 492 (S.C.C.) 
remote is not recoverable. However, where the type of injury is foreseeable, but the extent is not, full recovery will be granted. ${ }^{48}$

Where the physical loss is due to a negligent statement (where, for example, a physician tells an athlete his knee is fine when in fact all the ligaments are torn, and the athlete is injured through participation), then the plaintiff is entitled to recover.$^{49}$ Any attendant economic loss would, again, be recoverable.

In the sports malpractice situation, recovery for physical loss is not a particularly difficult situation to deal with. The principles relating to medical malpractice are easily applied to the liability of team physicians. The more difficult problem, however, is where the athlete suffers only pure economic loss.

\section{Pure Economic Loss}

The Courts have struggled with the problem of pure economic loss due to negligence. The primary concern is that if the test of remoteness used for physical loss were applied to pure economic loss, then the gates would be opened up to a flood of claims. As well, where the loss was due to a negligent misstatement, then it would seem unfair to hold people liable for an activity which by its nature is of ten imprecise.

The House of Lords considered the issue of pure economic loss resulting from negligent misstatements in Hedley Byrne \& Co. v. Heller. ${ }^{50}$ At one point, Lord Devlin ${ }^{51}$ looked at the distinction between physical loss and pure economic loss when both resulted from a negligent misstatement and gave the following relevant example:

If irrespective of contract, a doctor negligently advises a patient that he can safely pursue his occupation and he cannot and the patient's health suffers and he loses his livelihood, the patient has a remedy. But if the doctor negligently advises him that he cannot safely pursue his occupation when in fact he can and he loses his livelihood, there is said to be no remedy. ... I am bound to say, my lords, that I think this to be nonsense.

Similar circumstances may arise in the context of team physician liability where, for example, the team physician erroneously concludes that the athlete is not fit for participation and the doctor then either informs the athlete and the athlete foregoes participation, or he informs a third party and that party uses the information to require the athlete to forego participation - and pure economic loss results. In either case, the athlete may suffer the loss of a substantially large salary due to the team physician's negligence.

In order to avoid creating "liability in an indeterminate amount for an indeterminate time to an indeterminate class" 52 the courts established limiting principles. The Supreme Court of Canada looked at the problem in the context of accountants' liability to an investor who relied on financial statements prepared by the accountants. ${ }^{53}$ The Court chose to limit

48. Smith v. Leech Brain \& Co. Ltd. (1962) 2 Q.B. 405.

49. Clay v. A.J. Crump and Sons Led. (1964) I Q.B. 533 (C.A.); Robson v. Chrysler Corp. (Canada) Ltd. (1962) 32 D.L.R. (2d) 49 (Alta. C.A.).

50. (1963) 2 All E.R. 575.

51. Supra n. 50 at 603.

52. Ultramaresv. Touche Nivon \& Co. (1931) 255 N.Y.S. 170 at 179.

53. Haig v. Bamford et al. (1976) 72 D.L.R. (3d) 68. 
recovery to situations where the defendant had actual knowledge of a limited class of plaintiffs who would suffer economic loss as a result of the defendant's representations. The Court further left open the possibility that mere foreseeability of a limited class of plaintiffs may be used in some circumstances. But whatever the test, it appears that the negligent physician would be caught under either formulation, and liability would follow. ${ }^{54}$

\section{BASIC ELEMENTS}

Although a negligence action can be applied in a variety of situations, the basic elements are well settled. ${ }^{55}$ These are: ${ }^{56}$

1. Duty of care owed to the plaintiff by the defendant;

2. Breach of duty by the defendant;

3. Plaintiff must suffer injury or loss; and

4. The injury or loss must be the cause in fact and proximate cause of the defendant's conduct.

The two most important elements are the existence of a duty of care and the breach of the duty of care. Damages and causation in team sports physician liability should follow the same basic analysis as in medical malpractice liability. ${ }^{57}$

\section{DUTY OF CARE}

Beginning with first principles, the classic statement of duty of care is the neighbour principle enunciated by Lord Atkin in Donoghue v. Stevenson: ${ }^{58}$

The rule that you are to love your neighbour becomes in law you must not injure your neighbour; and the lawyer's question, Who is my neighbour? receives a restricted reply. You must take reasonable care to avoid acts or omissions which you can reasonably foresee would be likely to injure your neighbour. Who, then, in law, is my neighbour? The answer seems to be - persons who are so closely and directly affected by my act that 1 ought reasonably to have them in contemplation as being so affected when $I$ am directing my mind to the acts or omissions which are called in question.

From the neighbour principle it is evident that the essence of the duty of care arises from the relationship between the parties. The same is true for

54. It should be noted that the tests enunciated by the Supreme Court of Canada have not settled the issue of recovery for economic loss. What has been presented here is a brief look at some of the issues. A detailed analysis is beyond the scope of this paper.

55. Supra n. 33 at 92; Marshall, The Physician and Canadian Law (2nd ed. 1979) 54.

56. Some authors include other elements, such as the absence of any conduct by the plaintiff which would preclude him from recovering - Fleming, supra n. 16 at 105 , or the measure of damages recoverable - supra n. 14 at 26.

57. In the case of informed consent, there is a difficulty in determining the cause of the loss to the injured plaintiff because the court must assess whether the patient would have consented to the treatment had he been properly informed. The problem is exacerbated since the plaintiff will almost always use hindsight to say he would have foregone the treatment had he known of the risks. Therefore, the Supreme Court of Canada in Reiblv. Hughes, supra n. 2 at 15-17, adopted the objective test of causation whereby the court must not only be satisfied that this plaintiff would have foregone treatment, but also that a reasonable plaintif $f$ in the same situation would have done so.

58. Supra n. 39 at $\mathbf{5 8 0 .}$ 
physicians. Where a physician undertakes to attend a patient, he must use reasonable care and skill in treatment. A physician has no duty to accept a patient, but after having done so, the duty arises. ${ }^{59}$

Not only will an undertaking by a physician to attend a patient give rise to a duty of care but the physician is also said to have a fiduciary relationship with the patient. ${ }^{60}$ This relationship requires the physician to act honestly, and not put himself in a conflict of interest situation with the interests of his patient. ${ }^{61}$ The fiduciary nature of the relationship evolved from the notion that the physician was in a position of trust and confidence in matters pertaining to the patient. ${ }^{62}$ The duty placed on the physician is a high one indeed. ${ }^{63}$

Where a fiduciary relationship exists between a team physician and an athlete, there is an abundance of opportunity for conflicts of interest to arise. For example, it is quite clear that some team sports physicians would disclose confidential information to management, even if specifically requested not to by the athlete, because the physician sees the disclosure as an obligation to the team as part of his contract of employment. ${ }^{64}$ The fiduciary relationship requires the physician not to disclose such confidencial information to third parties. A breach of confidentiality by the physician may entitle the athlete to damages. ${ }^{65}$

Since a physician owes a duty to his patient based on the fiduciary nature of the relationship and not in contract, then the fact that the services of the physician were at the request of, and paid by, a third party should not alter the patient's ability to sue for negligence. ${ }^{66}$ However, it is at least arguable that where an employer hires a physician to examine employees (for example, to determine the employee's eligibility for life insurance), the physician owes no duty to the employee. This situation is somewhat analogous to the team physician treating the athlete at the request of team management.

The issue as to whether a physician employed by a third party employer owes a duty of care to a patient/employee probably revolves around which of the employer or employee stands to benefit from the examination. If the employee has a reasonably legitimate interest in the outcome of the examination, a duty should be held to exist. In the professional team sports situation, examples might include situations where the team physician conducts pre-season medicals which if failed would result in pecuniary loss to the athlete because of suspensions, or where the team physician conducts an examination following rehabilitation, which if passed would result in financial gain through participation. In these

59. Hurleyv. Eddingfield (1901) 59 N.E. 1058 (Ind. S.C.); E.L. Haines, "Courts and Doctors" (1952) Can. Bar Rev. 483 at 487.

60. Kenny v. Lockwood (1932) I D.L.R. 507 (Ont. C.A.); Halushka v. U. of Sask. (1965) 53 D.L.R. (2d) 436 (Sask. C.A.).

61. Ralston v. Tanner(1918) 43 O.L.R. 77 (Ont. S.C.).

62. Supra, n. 33 at 19.

63. D.M. Harney, Medical Malpractice (1973) 7.

64. Supran. 10.

65. See A.B. v. C.D. (1851), 14 Dunlop's S.C. 177 (Scot. C.S.).

66. B.J. Thomson, "Claims Arising Out of the Relationship Between Doctor and Patient", (1963) L.S.U.C. Spec. Lec. 185 at 189. 
cases, the benefit flowing to the athlete is a financial one, but this is not imperative: what is required is a reasonably legitimate interest. Therefore, it is submitted that the case of an error in diagnosis by the team physician, coupled with a later loss to the athlete, will indicate a sufficient interest on the part of the athlete to create a duty of care.

On the other hand, if the purpose of the examination is to benefit the team only, then no duty from the physician to the employee should result. Again an example involving professional athletes might include the situation where the purpose of the examination is to determine whether the athlete should be traded. In this case, the athlete does not have a reasonably legitimate interest because he neither suffers financially nor physically should a trade result. Therefore, it is arguable that under these limited circumstances no duty should arise.

However, it is evident that Canadian judges are quick to find a duty of care in circumstances where there is no apparent benefit flowing to the employee. The employer/doctor/employee cases are good illustrations. For example, in Leonard v. Knott ${ }^{67}$ a "client" of the defendant physician was examined under an executive health care package provided for by the employer. The employee died as a result of the physician's negligence. It was held that there existed a doctor-patient relationship even though the medical examination was at the request of, and paid for by, a third party. The trial judge in Leonard v. Knott quoted the following extract from the case of $R$. v. Bateman: ${ }^{68}$

The law as laid down in these cases may be thus summarized: - "If a person holds
himself out as possessing special skill and knowledge and he is consulted, as possessing
such skill and knowledge by or on behalf of a patient, he owes a duty to the patient to
use due caution in undertaking the treatment. If he accepts the responsibility and under-
takes the treatment and the patient submits to his direction and treatment accordingly,
he owes a duty to the patient to use diligence, care, knowledge, skill and caution in ad-
ministering the treatment. No contractual relation is necessary, nor is it necessary that
the service be rendered for reward".

The defendant physician was found liable for performing a test which carried such a high risk that any reasonable physician in similar circumstances would not have performed it. But a second physician whom the defendant had referred the patient to (and who actually performed the test which resulted in the plaintiff's death) was not liable because in performing the test it was reasonable for the second physician to rely on the judgment and reputation of the defendant. It is significant that on appeal, the British Columbia Court of Appeal found that even the referredto physician was negligent since he should not have performed the test in the circumstances. ${ }^{70}$ In other words, the referred-to physician owed a duty of care by undertaking to do the test at the request of a third party.

Although this decision might be explained on a basis that some benefit flowed to the plaintiff in that he had a reasonably legitimate interest in the outcome of the examination - both in terms of financial interest and

67. (1978) 5 W.W.R. 511 (B.C.S.C.).

68. (1925) 41 T.L.R. 557 at 559.

69. Supran. 67 at 513.

70. Leonard v. Knott (1980) 1 W.W.R. 673 at 685-686. Craig, J.A. dissented on the view that the referred-to physician was negligent; but his conclusion was based on standard of care, not duty. 
physical loss - no such analysis was undertaken by the Court. This case supports the view that the courts may establish a duty of care with relative ease in malpractice cases.

In Robitaille v. Vancouver Hockey Club 71 the plaintiff athlete was seriously injured due to previous injuries which the team management and physicians ignored. Esson, J. found the team management negligent, and further found the team vicariously liable for the negligence of the team physicians. Although no analysis was focused on the duty of the team physicians, the learned judge found that a duty of care was owed to the plaintiff. ${ }^{72}$ Furthermore, the Court of Appeal unanimously upheld the trial judge's finding of vicarious liability, but again without analysis of the duty issue. ${ }^{73}$

Rather than attempting to find similar fact situations where a duty was held to exist where a physician treated a patient at the request of an employer, a more general approach to the duty issue may be found in the test recently enunciated by the House of Lords in Anns v. Merton London Borough, ${ }^{74}$ per Lord Wilberforce:

\begin{abstract}
Through the trilogy of cases of this House - Donoghue v. Stevenson (1932) A.C. 532; Hedley Byrne \& Co. v. Heller \& Partners (1964) A.C. 465, and Home Office v. Dorset Yacht Co. (1970) A.C. 1004, the position has now been reached that in order to establish that a duty of care arises in a particular situation, it is not necessary to bring the facts of that situation within those of previous situations in which a duty of care has been held to exist. Rather the question has to be approached in two stages. First one has to ask whether, as between the alleged wrongdoer and the person who has suffered damage there is a sufficient relationship of proximity or neighbourhood such that, in the reasonable contemplation of the former, carelessness on his part may be likely to cause damage to the latter - in which case a prima facie duty of care arises. Secondly, if the first question is answered affirmatively, it is necessary to consider whether there are any considerations which ought to negative, or to reduce or limit the scope of the duty of the class of person to whom it is owed or the damages to which a breach of it may give rise: see Dorset Yacht case, per Lord Reid.
\end{abstract}

The test contemplates the use of the neighbour principle to find a duty of care where the relationship is proximate. The test goes on to include limiting factors which ought to reduce the scope of the duty.

Arguably, where there is no benefit flowing to the athlete because he has no reasonably legitimate interest, it would be unfair to impose a duty of care on the physician when he has not consented to accept it. The physician owes allegience to his employer ${ }^{75} \mathrm{On}$ the other hand, the mere fact that the physician is examining the athlete should give rise to a duty of care because of the reasonable expectations of the athlete. It would be reasonable that the team physician should inform the athlete of any complications or difficulties. Furthermore, the physician's professional status and fiduciary relationship ought to be a significant consideration in proving a duty of care. The first principle of the Code of Ethics of the Canadian Medical Association states: ${ }^{76}$ "Consider first the well-being of

71. Supran. 12.

72. Supran. 12 at 175.

73. Robitaillev. Vancouver Hockey Club(1981) 3 W.W.R. 481 at 500 (B.C.C.A.).

74. (1978) A.C. 728 at 751 .

75. King, "The Duty and Standard of Care for Team Physicians" (1981) 18 Houston L.R. 657 at 671 .

76. Supra n. 55 at 13. 
the patient", (emphasis added). It appears that most professional team physicians see themselves as owing a duty first to the athlete patient and only secondarily to the team. ${ }^{77}$ Therefore, a prima facie duty of care is likely to arise.

The second part of the Anns test deals with an analysis of factors which should reduce the scope of the duty. A potentially effective way to achieve this result is through the use of exclusion clauses. The main problem is that the exclusion of liability by the team for negligent acts of its team physicians will be ineffectual against the injured athlete because of privity of contract. ${ }^{78}$ It would seem that a team physician could limit his liability only if he were to contract with each individual player. Not only would this be impractical, but also it raises the whole issue of fundamental breach. ${ }^{79}$

The fundamental breach of a contract occurs where the exclusion clause is so onerous that it goes to the root of the agreement - it is against what was contemplated by the contract as a whole. In other words, limiting a team physician's liability for negligence may be viewed as an exclusion of the essential nature of the contract and should therefore not be upheld.

On the other hand, notwithstanding possible contract exclusions, the team physician may owe a duty of care to the athlete based on the fiduciary nature of the relationship. The team physician may try to limit liability not by excluding it in contract but by reducing the scope of the duty in tort; that is, the physician would place limitations on the circumstances in which he could be held liable. But it is important that the athlete be made aware of the scope; a clear delineation of the scope of duty between team management and the physician is not notice to the athlete. ${ }^{80}$

American authorities suggest that physicians are free to set limitations for their practices in relation to working hours, radius of travel, locations at which services are rendered, scope of services of fered, and priorities among patients' needs"'.81 Commonwealth authorities are less clear, but the Anns test contemplates that a physician is entitled to reduce his scope of duty in some situations. The real problem is determining to what extent he may do so. There is no simple answer because the scope of duty is very closely related to the standard of care, ${ }^{82}$ the two almost being indistinguishable. And as will be discussed shortly, the standard of care required of team physicians is unsettled. ${ }^{83}$

Since the nature of the physician-patient relationship is one which is fiduciary, it would be repugnant to the notions of trust and confidence if the physician were permitted to limit the scope of his liability where he

77. Supran. 10.

78. Scruttons Ltd. v. Midland Silicones Ltd., supra n. 22. See also discussion, supra n. 22 and accompanying text.

79. See generally, Waddams supra n. 25 at 283.

80. Supran. 75 at 682 .

81. Louisell \& Williams, Medical Malpractice(1960) 192.

82. Supran. 33 at 93.

83. Infra Part VI. 
undertook to render emergency care to others. The physician in such circumstances should be obliged to render his medical services in a reasonable manner because the injured athlete justifiably relies on the physician (or team) to provide these services in the course of his employment. In other situations, the scope may be limited by the same reasoning. For example, if the athlete is well aware that the team physician's services are provided only for the care and treatment of injuries resulting out of sport participation, then it would be unreasonable for the athlete to expect the team physician to render general health care services. The athlete in these circumstances should consult his own family physician.

On the other hand, the fiduciary relationship may require that where the team physician actually discovers a potentially dangerous condition during an examination (the purpose of the examination being to focus on sports related ailments), he must at least inform the athlete so that the athlete can take the initiative to further investigate. The team physician's obligation to notify the athlete may even go so far as requiring the physician to diagnose conditions which he ought reasonably to have diagnosed. In any event, the ability of the team physician to limit the scope of his duty may be restricted by the fiduciary nature of the relationship. A better route to limit liability might be to consider the standard of care required of professional team sports physicians.

\section{STANDARD OF CARE}

The most difficult element in establishing the liability of professional team physicians relates to the standard of care. Because of the unusual position the team physician finds himself in, there are a number of factors which alter the "traditional" basis for determining standard. Before analyzing these factors, a brief overview of how the standard of care is established in negligence actions will be considered.

Negligence law requires that people should act in a reasonable manner, and are therefore judged by the "reasonable man" standard.84 Where someone acts unreasonably thereby causing injury to another, the wrongdoer will be liable to the person injured.

Normally the standard of care balances the probability of harm and the seriousness of the foreseeable injury with the cost of remedial measures and the social utility of the activity. ${ }^{85}$ Conduct which is "too risky' is unreasonable.

Whereas in normal circumstances the standard of care is determined in relation to the "reasonable man", a modified standard of care is used for physicians, that being "a reasonable medical man considering all the circumstances". ${ }^{86}$ Reasonableness of ten encompasses custom as a factor -

84. Supran. 39.

85. Bolton v. Stone (1951) A.C. 850 (H.L.).

86. Cryderman v. Ringrose (1977) 3 W.W.R. 109 at 118 (Alta. S.C.); affirmed (1978) 3 W.W.R. 481 (Alta. C.A.). 
especially in medical liability cases. ${ }^{87}$ The applicability of custom as a major factor in determining the standard of care is questionable. ${ }^{88}$

Historically, if a medical man could show he acted in conformity with the established medical practice then it was almost conclusive that he met the required standard of care ${ }^{89}$ For example, in Jewison v. Hassard ${ }^{90}$ the plaintiff was operated on by the defendant physician, but through error, a sponge was left behind after surgery. The plaintiff's action against the physician was unsuccessful because the surgeon was "too busy with his other work to keep count of the sponges" and his actions in delegating authority were reasonable in the circumstances. ${ }^{91}$ The same was true where diagnosis was performed in the customary manner. ${ }^{92}$

In recent times, there has been a trend to recognize that custom is not determinative of standard in medical liability cases. The true principle was borne out by Shultz, J.A. in Pennerv. Theobald when he said:93

While it is true that in the great majority of alleged malpractice cases a charge of negligence can be met by evidence to the effect that what was done was in accordance with the general and approved practice, nevertheless, it is the Courts and not the particular profession concerned which decide whether negligence is established in a particular case.

An extension of this principle has occurred where the negligence action is based on lack of informed consent. The standard depends on the information the plaintiff requires in the circumstances. In the recent Ontario High Court decision of White v. Turner, Linden, J. put it this way: 94

\begin{abstract}
Further, in analyzing the quality and quantity of the information given to a patient under negligence principles, the test to be employed is no longer the professional medical standard, heretofore used by our Courts, but rather the reasonable patient standard. This is a major shift heralded by the Supreme Court of Canada in Reibl v. Hughes, supra. No longer does the medical profession alone collectively determine, by its own practices, the amount of information a patient should have in order to decide whether to undergo an operation. From now on, the Court also has a voice in deciding the appropriate level of information that must be conveyed to a patient in the circumstances as a question of fact.
\end{abstract}

Where a physician holds himself out to be a specialist he must "exercise the degree of skill of an average specialist in his field" .95 The area of sports medicine is not generally considered a "specialty". The Canadian Medical Association treats sports physicians as general practitioners. However, there is some indication that sports medicine is becoming a

87. McDanielv. Vancouver General Hospital (1934) 4 D.L.R. 593 (P.C.).

88. See Wright and Linden, Canadian Tort Law: Cases, Notes \& Materials, (7th ed. 1980) 4; "Determining the Standard of Care in Malpractice Cases"' (1966) 4 Osgoode Hall L.J. 222 at 226.

89. Marshallv. Lindsay County Council, (1935) I K.B. 516 at 540.

90. (1916) 28 D.L.R. 584 (Man. C.A.).

91. Supran. 90 at 585.

92. Pennerv. Theobald (1962) 35 D.L.R. (2d) 700 (Man. C.A.).

93. Supra n. 92 at 712, citing Andersonv. Chasney (1949) 2 W.W.R. 337 (Man. Q.B.); (1949) 4 D.L.R. 71 (Man. C.A.); reversing in part; (1948) 4 D.L.R. 458; affirmed (1950) 4 D.L.R. 223.

94. (1981) 120 D.L.R. (3d) 269 at 283 (Emphasis included).

95. Supran. 5 at 817 per Abbott, J. 
specialty, at least in the opinion of some writers. ${ }^{96}$ If this is so, the standard of care required of professional team sports physicians would be considerably higher than that required of general practitioners, namely, the degree of skill, care and judgment of an average specialist in sports medicine. On the other hand, given the relative infancy of the sports medicine field and the Canadian Medical Association's view of the problem, it is more than likely that sports medicine in Canada has not yet developed into a specialty.

Despite the number of cases dealing with the standard of care required in medical malpractice, there has been no Canadian judicial analysis or academic comment on the standard required of professional team sports physicians. Once a doctor-patient relationship is found to exist, prima facie the standard is that required of general practitioners. However, there are many unique features of the relationship which could alter the traditional standard. In fact, even the employer/doctor/employee cases are of little assistance in this respect because of the nature of the professional sports relationship.

The most significant factor affecting the doctor-patient relationship is the existence of pressure on all parties. Of particular importance are the pressures on the athlete and the team physician. ${ }^{97}$

\section{A. PRESSURES ON THE ATHLETE}

The coach exerts a high degree of pressure on the athlete to perform despite the existence of an injury which can severely affect performance. This was shown to exist in the Robitaille case ${ }^{98}$ where the coach and club doctors said that the athlete's problems were "all in his head" and that he should continue to play. He did play and the result was a permanent disability.

Team management can put pressure on the athlete through the threat of dismissal or trade for non-performance. According to Tony Gabriel, former professional football player for the Ottawa Rough Riders of the Canadian Football League, one of the three worst fears an athlete can have is the fear of being cut from the team. ${ }^{99}$ The number one fear is that the athlete may be dropped from the team due to injury. This sort of pressure could result in the athlete requesting (or demanding) special treatment from the team physician in order for the athlete to maintain his standing with the team.

A more subtle form of pressure is that of job security. The athlete may suffer an injury, and thereafter his replacement may win the new opening at the expense of the injured athlete. For example, ${ }^{100}$ in the 1920 's Wally Pipp was the first baseman for the New York Yankees baseball club. He missed one afternoon and was replaced by Lou Gehrig who went on to play 2,130 consecutive games as first baseman. Jim Young, former pro-

96. Smith, "Sports Medicine Doctors Find New Ways to Treat the Breaks of the Game", (1982) 7:11 Alberta's Western Living 8 at 12.

97. Pitt, "Malpractice on the Sidelines: Developing a Standard of Care for Team Sports Physicians" (1980) 2 J. Comm. \& Ent. L. 579.

98. Supran. 12.

99. Gabriel and Fillmore, Double Trouble(1978) 178.

100. Supran. 97 at 590. 
fessional football player for the B.C. Lions of the C.F.L. put it this way:"101 ". . . A sprained ankle could spoil your weekend. It could kill my career. Before I got back, someone else could have my job."

The team also has access to the media which, if the team so desires, may foster the impression that the athlete is not performing up to his potential. A professional hockey player who voices his concerns about his health and safety may quickly be dubbed a "malingerer". ${ }^{102}$ Public opinion is a major source of anxiety for many athletes. ${ }^{103}$

Often the teammates of the injured athlete will exert pressure both while playing the game and in social activities. This is especially true where the athlete's peers believe he is "faking" the injury merely to avoid playing while at the same time taking advantage of a wage continuation clause in the player's contract. ${ }^{104}$

An athlete may put pressure on himself by trying to live up to the image of "machismo"."105 Many professional athletes believe their masculinity is defined by the amount of pain they can withstand. Jim Young looked at professional football in this way: ${ }^{106}$

Healthy, anyone can play. The star is the guy who turns his back to catch a pass when he knows he's about to get driven; when he knows he can lift only one arm; when he knows that if he gets his knee hit again, or that spot in his back, or his ribs, the whole season is over. Football is the art of rising above pain.

In order to sustain the "macho" image, players of ten resort to various sorts of pain killers supplied by the team physician to reduce the pain during game day. The ease in which players can receive these drugs is openly confessed, ${ }^{107}$ but apparently justified on the basis that a professional athlete is under tremendous pressure to perform; the athlete's career is on the line.

\section{B. PRESSURES ON THE TEAM PHYSICIAN}

Coaches insist that their athletes must be ready to play, and this puts pressure on the team physician to perform miracles quickly. The physician must balance "good medical treatment" with "rapid short-term recovery"; 108 the two not of ten being congruent. ${ }^{109}$ Failure to perform could result in the replacement of the team physician.

101. Young and Taylor, Dirty $30(1974)$ at 73.

102. Supran. 12 at 164 .

103. Supra n. 11 .

104. The current C.F.L. Standard Player's Contract provides:

$21 . .$. [I]f the Player . . . is injured ... and the injury or injuries are such as to render him unfit to play skilled football during the current football season or any part thereof, the Club shall pay to the Player . . . 100\% of [his] salary. ...

Similarly, the current N.H.L. Standard Player's Contract provides:

S.(d) [If] the Player . . . is disabled and unable to perform his duties as a hockey player by reason of an injury . . . he shall be entitled to receive his remaining salary due. ...

105. "Exaggerated awareness and assertion of masculinity" - Webster's New Collegiate Dictionary (5th ed., 1977) as quoted from Pitt, supra n. 97 at 588.

106. Supran. 101 at 74 .

107. Supra n. 10.

108. Hirata, The Doctor and the Athlete (2nd ed. 1974) at 12 and 21.

109. Supran. 10. 
A team physician, like any other physician, is licensed to prescribe drugs. But in the context of sports medicine the team physician is under more pressure to prescribe drugs to an athlete than he would otherwise be. The presence of drugs in the locker room is evident when players like C. Oliver, a former N.F.L. player, stated "If Pete Rozelle, the (NFL) Commissioner, put a lock on the pill bottle, half the players would fall asleep in the third quarter . . ", 110 or Jim Young, a former C.F.L. player said:

My mainlining was done for me by a medical staff. It wasn't speed or horse or acid, it was painkiller ... But certain kinds of dope (painkiller) are a necessary part of athletics."'

The prescription of drugs to athletes might be rationalized on the basis that performance would increase or corrective treatment would be delayed. However, it has been argued that the negligent prescription of drugs should result in team sports physician liability because the athlete may not have had full disclosure of the risks involved, or the drug may cause or worsen an injury. ${ }^{112}$

Many physicians consider sports medicine to be prestigious for the few professionals who are fortunate enough to be part of the trend. The physicians are generally keen fans of the sport and are happy to pursue an opportunity to be part of a professional sports organization. ${ }^{113}$ The prestige or status involved could be sufficient to pressure the team physician into putting the team management interests before those of the athlete. A conflict of interest may arise: ${ }^{114}$

I don't see how you can have a physician hired by management, reporting to management, and treating the players and not reporting to them. It's the physician's duty to inform the patient of his condition. His prime obligation is to the patient.

Furthermore, the team physician is in a conflict as he is caught between his duty to an athlete and his contract of employment with the team. When the physician is employed by the team,

the doctor will have a duty to the (team) to perform services in accordance with the express or implied requirements of the contract and may be responsible for damages caused by a failure to perform those requirements. ${ }^{115}$

Both the Hippocratic Oath and the Code of Ethics of the Canadian Medical Association ${ }^{116}$ recognize that a physician's first concern should be to the patient. But there has been some judicial recognition that a professional sports physician may have his primary obligation owed to the team: ${ }^{117}$

The primary responsibility of the doctors was recognized as being to the club. That was even true where the treatments involved of fice consultation and operations. . . The doctors recognized an obligation to advise the club of their conclusions and advice.

110. Oliver, High for the Game, as quoted in Pitt supra n. 97 at 591.

111. Supran. 101 at 72.

112. Supran. 29 at 995.

113. Supran. 12 at 172.

114. Dick Butkus, former football player with the Chicago Bears, as reported in the Philadelphia Inquirer, (Sept. 28, 1976) as quoted from Appenzeller \& Appenzeller, Sports and the Courts (1980) 240.

115. Supra n. 29 at 991.

116. Marshall, supra n. 55 at 12.

117. Supran. 12 at 173. 


\section{OTHER FACTORS}

The doctor-patient relationship is also affected by many other factors which make it difficult to determine the standard of care required of team physicians. These include: (1) the absence of a general or special nationally recognized standard of care which exists for other physicians; (2) team sports physicians have ranges of expertise from general practitioner to orthopedic surgeon; ${ }^{118}$ (3) there are very few professional team physicians in Canada; (4) sports medicine is a recent development; (5) the injuries are of ten specialized in nature, but can be of a general character; and (6) the medical equipment and facilities available to the professional team sports physician are of ten more modern, efficient and specialized than would be the case for other medical fields.

\section{THEORIES ON STANDARD OF CARE}

It is clear, then, that the team physician can find himself in a conflict situation where he is trying to balance the interests of his employer with those of the athlete. The problem is determining how the standard should be varied in light of this conflict. Various theories are suggested.

\section{A. NORMAL DOCTOR-PATIENT STANDARD OF CARE THEORY}

The simplest answer to the problem of determining the applicable standard of care for professional team sports physicians is to adopt the standard used for the normal doctor-patient relationship. The team physician would be bound to exercise the degree of care which would reasonably be expected of a normal and prudent practitioner of similar experience and standing. ${ }^{119}$

Although this characterization has the benefits of ensuring a minimum standard of care, and is simple and familiar, it is suggested that this standard ignores the realities of the conflicts which exist in the doctor-patient relationship. A physician in private practice answers to his patient, not to the physician's employer.

\section{B. SPECIALIST TEAM SPORTS PHYSICIAN STANDARD OF CARE THEORY}

A slight variation on the normal doctor-patient standard of care is the establishment of a "specialist" standard applicable to professional team physicians. The standard would be one which the law could recognize as involving a greater degree of skill and care than would otherwise be expected: 120

There is ample authority to suggest that the team physician's standard of care can be partly based on the standard of care in the usual physician-patient relationship. The team physician, who renders services to an athlete, indicates that he possesses a degree of skill similar to that of other team physicians in good standing. At the same time, the unique characteristic of medical malpractice in professional sports must be recognized.

118. Supran. 10

119. Crits v. Sylvester(1956) 1 D.L.R. (2d) 502 and 508 (Ont. C.A.).

120. Supran. 97 at 593. 
The team physician standard of care would, however, pay little consideration to the external forces on the doctor-patient relationship: ${ }^{121}$

The existence of influences outside the (doctor-patient) relationship should not af fect the quality of care or duty to provide it. If the physician fails to exercise care in treating the athlete, he should be subject to liability for negligence irrespective of outside influences.

The end result is that the professional sports team physician would be required to perform using the skill of a specialist in his field since the physician has greater abilities than those of a general practitioner.

The specialist theory can be attacked primarily on the ground that, at least in Canada, there is no recognized or established 122 "specialty" in the area of sports medicine. Team physicians come from divergent backgrounds and have little or no formal training in relation to athletic injuries. Further, there are very few professional team sports physicians, and of those, even fewer perform their functions on a full-time basis. ${ }^{123}$ Therefore, it is suggested that a specialized standard of care would not only be difficult to establish and apply, but also would fail to consider the anomalous nature of the doctor-patient relationship.

\section{HOLDING OUT THEORY}

Where a team physician possesses special qualifications, such as being an orthopedic surgeon, the standard of care required of him would be higher than that of a general practitioner performing similar duties. ${ }^{124}$ But where a physician does not actually possess those qualifications and yet holds himself out as possessing special skills, then the physician will be required to live up to the same standard as members of that specialty. ${ }^{125}$

The holding out theory of liability is reasonable where a team physician attempts to perform non-emergency functions beyond his capabilities and fails due to his negligence. The reasonable expectations of the athlete have not been met. But more important is the fact that the standard of care is determined not by what the physician's actual qualifications are, but by what they appear to be. The result is an objective standard which would ensure a high level of competence from the team physician.

The holding out theory has the desirable characteristic of flexibility in relation to the circumstances in which it is applied. By considering the factors which affect the doctor-patient relationship, a court can vary the standard depending on what would be reasonable in the circumstances.

There are two main objections to the holding out theory. The first is that a team physician would be unable to conduct his affairs based on any kind of reliable and predetermined standard of care. If team sports physician liability were to be based on such a system, not only would this discourage physicians from entering the field of sports medicine, but also

121. Supran. 97 at 590 .

122. Marshall supran. 55 .

123. Supran. 10.

124. Challand v. Bell(1959) 18 D.L.R. (2d) 150 (Alta. S.C.).

125. Supran. 5 at 124. 
physicians would refrain from providing 'gratuitous' services to athletes for fear of being held to a higher standard of care. Of course this can be said of any physician who holds himself out as possessing special skills, but in the context of team physician liability, the situations where holding out could arise are far more common than would be the case for a general practitioner.

The second objection to the holding out theory is that even though consideration is given to the circumstances in which the team physician finds himself, the scope of the duty of care is ignored. Any qualifications which the physician can reasonably place on the relationship should have been evaluated when the relationship was entered into, and any "reasonable expectations" which the athlete may have formed which are outside the scope of duty should not be given effect to. That is, any inquiry into sports physician liability would not focus on the standard of care (and the various outside influences which could alter it), but on the scope of the duty.

\section{SCOPE OF UNDERTAKING THEORY}

The scope of undertaking theory of liability emphasizes that notwithstanding the outside factors which influence the relationship between physician and athlete, the standard of care for the professional team sports physician is to perform with the level of skill and care expected of a physician in reasonably similar circumstances, with the counterbalancing consideration being the scope of the undertaking. In other words: ${ }^{126}$

... the fact that the team physician is paid by the team does not lower the standard of care owed to the patient. But, the fact that the physician has undertaken duties with certain reasonable limitations in mind that are communicated to the athlete ... should be taken into account in evaluating the quality of the defendant's performance.

Therefore, the determination of the scope of the team physician's duty becomes the central question.

A physician is free to limit the scope of his liability by contract, but not to the extent where the exclusion of liability constitutes a "fundamental breach". ${ }^{127}$ Further, where liability is limited, the boundaries of it must be clearly delineated and communicated to all involved parties. ${ }^{128}$ This necessarily involves a separate contract between the physician and the athlete.

Although it may be possible for the team physician to limit his liability by contract principles, tort theory dictates otherwise. The doctor-patient relationship ${ }^{129}$ being one based in trust and confidence requires a physician to act in good faith and use his best judgment. To do so, he cannot unreasonably limit the scope of his duty. But there is nothing offensive about a physician limiting the occasions and circumstances in which he will render his services to team members - as long as all parties concerned are aware of the "ground rules".

The approach which a physician might consider in limiting the scope of his duty is as follows. First, the team physician must determine the essen-

126. Supran. 75 at 682.

127. Supran. 79.

128. Supran. 75 at 682.

129. See discussion supra $\mathrm{n} .60$ and accompanying text. 
tial nature of the doctor-patient relationship in the circumstances (considered primarily in terms of the normal doctor-patient relationship). For example, the normal doctor-patient relationship is premised on the notion that the patient's interests always come first. This requires the physician to exercise due care and skill when advising, treating, and operating on the patient. Second, the team physician must distinguish between the essential nature of the relationship and matters collateral to it. At the outer fringes of the doctor-patient relationship are duties which can be limited. This would include the situation where, for example, the patient seeks the services of his physician in order to mend a broken arm; if the physician fails to diagnose an ulcer, he should not be held liable since the purpose of the treatment was limited. ${ }^{130}$

The scope of undertaking theory achieves the best results for all the parties concerned. The team physician is required to live up to the standard of care of a reasonable physician in similar circumstances, notwithstanding the pressures of the relationship. When the physician undertakes to perform a service, he must do so with reasonable skill, care and judgment, which is a standard with which he is familiar. Furthermore, the team physician has the onus to consider all the factors which affect the doctor-patient relationship, and these can be incorporated into his limitation of the scope of duty. The athlete is protected from unreasonable conduct on the part of the team physician. Most injuries will be within the scope of the team physician's duty; only those collateral to the relationship may be limited.

\section{CONCLUSIONS}

It is clear that Canadian courts will likely find that a duty of care arises between the professional team sports physician and the injured athlete either because of the neighbour principle, the fiduciary relationship, or both. Once the duty is found to exist, the scope of that duty must be determined bearing in mind the nature of the contract between the physician and the athlete, the exclusion clause, the fiduciary nature of the relationship, the pressure surrounding the relationship, and other factors relevant in the circumstances.

Once a duty is found to exist, the standard of care required of professional team sports physicians must be examined. Due to its nature, the standard is determined by the peculiar circumstances of each case. Various theories of liability have been advanced in an attempt to deal with the unique nature of the doctor-patient relationship. Of these theories the scope of undertaking theory was found to best meet the needs of both the physician (in that he could conduct himself according to a pre-determined standard) and of the athlete (in that his reasonable expectations would be upheld). However, a note of caution is warranted because a determination of a theory for the standard of care required of

130. Of course, where the physician undertakes to treat a collateral ailment, he may be held liable for negligence if his conduct is below the acceptable standard - based either on the holding out theory or on the fact that the scope of undertaking was broadened through the physician's acts. 
professional team sports physicians is somewhat artificial as being divorced from the facts of the particular case. Just the same, generalities are a helpful basis in focusing on relevant issues and considerations.

In the United States, the potential liability of professional team sports physicians is becoming a significant issue because of the high salaries paid to both the athletes and the physicians, and because the level of sophistication of professional athletics is far advanced. Some American decisions have clearly shown the importance of the area. In Canada, team physician liability has not yet hit the court room with the same impact as it has south of the border. But this should not mitigate the need for developing early guidelines to prevent later litigation. 